\title{
Article
}

\section{Deconstructing the Political Umma : Mohamed Talbi on Discursive Shift and Political Islam}

\author{
Al-Dakkak, Kelly Lynn \\ Available at http://clok.uclan.ac.uk/29643/ \\ Al-Dakkak, Kelly Lynn (2019) Deconstructing the Political Umma : Mohamed \\ Talbi on Discursive Shift and Political Islam. The Muslim World, 109 (3). pp. \\ 278-288. ISSN 0027-4909
}

It is advisable to refer to the publisher's version if you intend to cite from the work. http://dx.doi.org/10.1111/muwo.12291

For more information about UCLan's research in this area go to http://www.uclan.ac.uk/researchgroups/ and search for < name of research Group>.

For information about Research generally at UCLan please go to http://www.uclan.ac.uk/research/

All outputs in CLoK are protected by Intellectual Property Rights law, including Copyright law. Copyright, IPR and Moral Rights for the works on this site are retained by the individual authors and/or other copyright owners. Terms and conditions for use of this material are defined in the policies page.

\section{CLoK}

Central Lancashire online Knowledge www.clok.uclan.ac.uk

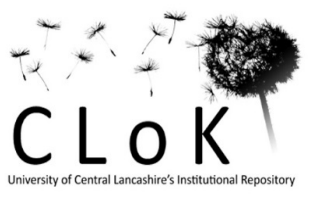




\title{
Deconstructing the Political Umma: Mohamed Talbi on Discursive Shift and Political Islam
}

\author{
Kelly A1-Dakkak \\ University of Central Lancashire
}

$\mathrm{M}$ ohamed Talbi was a Tunisian academic whose historical and religious writing has both influenced and reflected important developments in the debate on the nature of Tunisian identity and society. He was born in I92I and died in May 20I7. From 2007 to 20I2, I conducted a series of interviews with him in which I explored his methodology - his 'vectoral reading of the Qur'an' - and his resulting conclusions on a number of important questions for Tunisian society. Among the topics that Talbi visited most frequently was the nexus of Islam and politics in Tunisia and in the greater Arab world. He was known as an opponent of political Islamic thinkers; in this context, he wrote extensively on the manner in which Tunisians specifically and the Arab world more generally use the word umma, a topic that he viewed as closely related to the trend of the politicisation of religion.

\section{Analytical method}

To understand Talbi's contribution in this area, one must first understand his method of analysis. Talbi advocates a reading of sacred text in which the Qur'an is to be read and interpreted in the context of the conditions surrounding it at the time of the revelation. Using this method, Talbi argues that one can derive a set of universal, ethical principles from the Qur'an, a core of the religion that he describes as visible to all of us due to our innate sense of right and wrong. Talbi refers to this sense as fitra. Talbi believes that these principles are the core of Islam, to be contrasted with time bound injunctions in the Qur'an, which may be set aside with changing social conditions. The core principles derived from religious text may then be applied to find solutions to contemporary social questions. Using this method, Talbi has produced a body of writing which continues to influence society and politics in Tunisia and throughout the Arab world.

Like many other Islamic thinkers in the modern age, Talbi advocates a methodology wherein the law contained in the madhähib is implicitly marginalised. Rather than relying on earlier opinions, Talbi's method entails a return to the Qur'an as the source of his epistemological foundations. For Talbi, the Qur'an is Islam. Thus, on those occasions when he cites the opinions of classical $^{\mathrm{I}}$ and modern $^{2}$ writers, he does so with the intent of comparing their conclusions to his

\footnotetext{
${ }^{\text {I }}$ Note, for instance, Talbi’s reference to Hishām Ibn ${ }^{\mathrm{c}} \mathrm{Abd}$ Al-Malik in M. Talbi, 'Iyäl Allāh [Families of God] (Tunis: Ceres Editions, I992), 8I.

${ }^{2}$ See, for example, references to the work of Rashīd Riḍā and Muhammad 'Abduh in: M. Talbi, Ummat al-Wasat [Community of Moderation] (Tunis: Ceres Editions, I996), I29.
} 
own. Never does Talbi cite earlier analysis as source material for his own interpretative process. Rather, the writers who have influenced his method and conclusions have done so in an oblique manner. Talbi maintains that his method represents a return to fresh interpretation, a process which any or all members of society are encouraged to take up.

Thus, Talbi encourages his reader to perform ijtihäd. This he defines as, "a continuous quest or a search without interruption and without satisfaction with that which has [already] occurred. When correctly understood, $i j t i h a \bar{d}$ is a good thing, because every person is a mujtabid, or should be a mujtabid."'3 Indeed, this final qualification is critical to Talbi's understanding of $\ddot{j} t i h \bar{a} d$, as he defines the term generally enough that daily and mundane decisions are included. Thus, by necessity, he argues that we are all mujtabidin. No training or qualification is necessary, as Talbi does not,

limit ijtihäd to a specific person, meaning that I do not give this term the technical meaning that I give it in theological or fiqh cases specifically. Of course, specialisation exists in these areas, and I consider specialisation to be a necessity; however, each person must conduct ijtihäd in life ... So, why should $i j t i b a \bar{d}$ be limited to a specific class of person? If every one of us is a mujtabid in his life, of course, [this will bring] humanity a great good. ${ }^{4}$

It is clear that in this passage, Talbi defines $i j t i h a \bar{d}$ with none of the methodological rigour that characterises the work of classical scholars, ${ }^{5}$ or indeed, the work of many of his contemporaries. At the same time, Talbi is adamant throughout his writing that such rigour is critical to his work and that it is his historical method that ensures this quality.

\section{Deconstructing governance}

To understand Talbi's writing on the meaning and implications of umma, it is necessary first to apply the methodology outlined above to the subject of Islamic governance. Throughout his career, Talbi has written prolifically on the subject, but three strands of thought recur most frequently in his body of work. First of all, Talbi has written a great deal criticising thinkers who equate shürà to democracy. He specifically cites the work of North African scholars such as Allal El-Fassi as examples of what he calls the Salafi trend of oversimplification. He describes writers such as the Moroccan scholar as, "before all else, Salafists who remained prisoners to conservative thought." While he takes specific issue with El-Fassi's work, Talbi's critique is extended to all writers who have found justification for modern political identity projects

\footnotetext{
3 M. Talbi, 'Iyāl Allāh, 46.

4 Ibid.

5 By the eleventh century, for example, Abū-l-Husayn al-Basrī had articulated the following preconditions that an individual must meet before he may be considered a mujtahid: "he must possess an adequate understanding of the nearly 500 legal verses in the Quran ... he must be familiar with the hadith collections relevant to law ... Third, he must be knowledgeable of the Arabic language ... among other things, in metaphorical usages, in the general and the particular, and in equivocal and unequivocal speech. Fourth, he must possess a thorough knowledge of the theories of abrogation ... Fifth, he must be highly proficient in the entire range of the procedures of inferential reasoning ... Sixth, he must know those cases that have become subject to consensus, for he must not attempt to reopen a case on which a consensus has been reached." See: W. B. Hallaq, $A$ History of Islamic Legal Theories: An Introduction of Sunni Usul AlFiqh. (New York: Cambridge University Press., I997), II8.
} 
in religious history. Talbi does not object to the notion that religion should inform political choices. Rather, his objection to El-Fassi's work critiques his use of facile analogies, ignoring the historical reality of shürā and democracy as they were actually practised. Talbi argues that, without attention to such realities, writers can and frequently do universalise the words of the Qur'an, applying scripture to all sorts of modern political causes and movements, far from the original context. Talbi famously offered a deconstruction of both democracy and shürä, in an effort to demonstrate that the development of both concepts occurred in unlike contexts and according to unlike values. He concludes that there is evidence that shürä should form part of the universal, ethical core that his methodology seeks to derive. Democracy, in contrast, he finds to be a time bound institution, although he concedes that democratic institutions may satisfy the need for consultation inherent in shürä.

The second trend found throughout Talbi's writing on governance is his view, reiterated many times throughout his career, that if shürä is a universal principle common to all men, an abstraction, and an element of the ethical core of Islam - as he in fact argues - Muslim majority societies are left some element of choice on how best to realise shīrä in response to the social conditions of the time. Flexibility is inherent in such a formulation, as, in Talbi's words, "it is left to every age, to every generation, and even to every society as a function of their circumstances, to organise their affairs ... to avoid arbitrariness and everything that it brings in terms of injustice and oppression." "Thus, the question that modern society must ask itself is how to construct a social order around universal principles such as shürā. Once Talbi has established the core of good governance to be a universal concept, the task with which society is entrusted is one of constructing government to reach this highest of ideals. This approach stands in contrast to the intellectual methods of, again, in Talbi's words, "Salafis, who cling to the concept of shürä and Westernised modernists, who hold tight to that of democracy."'

\section{Understanding the umma}

Thirdly, and closely related to this, Talbi speaks out against what he deems to be a dangerous politicisation of the word umma itself. The remainder of this article will analyse his arguments in this area, found primarily in his writing in the mid-I990s, including Ummat al-Wasat and 'Iyäl Allāh, in addition to his Francophone writing and source material from the interviews that I conducted with him.

In the last twenty years of his life, Talbi became increasingly critical of shifts in the definition and usage of the word umma in modern literature. As in most of his writing, he qualifies his positions, stating that he is a writing as a historian, and not a fäqih. He reminds the reader than he does not have any leaning or political objectives, nor does he speak in the name of Islam. ${ }^{8} \mathrm{He}$ furthermore reminds us that he denies epistemological certainty in the realm of religion, asking, "who ... can pretend to have attained a level of infallibility that confers upon him the right to

\footnotetext{
${ }^{6}$ M. Talbi, Réflexion d'un musulman contemporain (Casablanca: Editions le Fennec, 2005), 78-9.

7 Ibid, 77. Talbi employs the term shürä here to refer to the historical interpretation of the universal concept found in Islamic society.

${ }^{8}$ Ibid, 83 .
} 
dictate the Truth? It's unthinkable." In Talbi's epistemology, only the Qur'an itself is truth. All else is limited to hypothesis. Talbi emphasises that, without epistemological certainty, debate and dialogue are among the highest of values. The most important thing, in this view, is "that I should be on equal footing with my partner in dialogue, that I can say what I think in a climate of liberty that I share with my interlocutor."IO

In the spirit of this debate, Talbi offers his opinion that the term umma represents one of the best examples of the trend of back-projection that he frequently critiques in his fellow historians - that impulse among intellectuals to attempt to assign a secular meaning to a uniquely religious concept. In his view, the umma, to avoid all ambiguity, must be a community of faith in the service of God, not a political entity nor a social institution outside the bounds of belief. Anything else ignores history and modern political reality. Talbi summarises his personal position succinctly, "Muslims are not of a single inclination. I believe that the umma is one in prayer and belief, but it is divided in other aspects, aside from the service of God."II

The nature of the umma, the uniting force of which is to be found in its spiritual mission, is in Talbi's view, "sui generis and a value in itself." ${ }^{2}$ In contrast to the umma, the traditional community, the clan, the tribe, and the nation all cease to exist with the elimination of ethnicity or the persons forming the community. It is impossible to define any of these groups outside of the framework of their constituent members. In this way, Talbi distinguishes the umma from other types of communities. In his words, "there is no Quraysh without Qurayshis, and you cannot become Qurayshi if you were not already." "I3 Talbi writes that the Jewish umma is of this type; it is an alliance borne of blood and a relationship to land. It is thus defined by its membership and the physical reality of its history.

In contrast, Talbi presents the Muslim umma as an entirely different type of entity, marking a new type of universalism unseen before its birth. Given that Muslims are defined by their response to the call to faith, their mission, and their belief, rather than their blood, the Muslim umma represents something eternal, "a category, and this category would continue to subsist by virtue of itself, unceasing, even if there were no more Muslims." 44 In some ways, he writes, it can be compared to the modern state, which defines itself based on its characteristics. In the same manner, the Muslim umma defines itself based upon belief characteristics. Thus, unlike the Jewish umma, the Muslim umma, a value in itself, is defined neither in terms of jus sanguinis, nor in terms of jus loci. Rather, as individuals respond voluntarily to the call of God, they affiliate themselves of their own free will and become a part of the umma's mission and scope.

Talbi defines that mission, and thus the raison d'etre of the umma, as consisting of two components - on one hand, the social and terrestrial, and on the other, the spiritual and super-terrestrial. This, he contends, is unlike the sacred-secular dichotomy found in the West. Instead, the worldly and the spiritual are complementary in Islam; one cannot exist without the other. There

\footnotetext{
${ }_{9}$ M. Talbi, Plaidoyer pour un Islam moderne (Tunis: Ceres Editions, I998), I05.

${ }^{10} \mathrm{Ibid}$, Io6.

${ }^{11}$ M. Talbi, Réflexion d'un musulman contemporain, 84 .

${ }^{12}$ M. Talbi, "La vie en communauté: Le point de vue d'un musulman," Islamocbristiana Io (I984), 85-90: 87.

${ }^{13}$ Ibid.

${ }^{14}$ Ibid.
} 
is no conflict between prayer and work. Instead, the Muslim - the member of the umma - in Talbi's words "in prayer and in work, is always the same man." 5 Talbi defines the mission of the umma as including a vertical and a horizontal dimension. Man, in his relation with God, gives character to the vertical dimension. The five daily prayers and reflections on the Qur'an, thus, form part of the umma's mission. At the same time, man lives his membership in the umma by virtue of a horizontal dimension, his relationship with his fellow man and with society in general. Zakät falls into the scope of the horizontal mission of the umma.

Talbi argues that the horizontal dimension of the umma, as it entails social obligations, is the subject of some ambiguity in modern literature. In contrast to his own reading of the term, Talbi notes that writers have consciously or unconsciously attributed to the umma a political dimension, a component which Talbi argues has absolutely - he states this in very strong language - no root in the Qur'an. Hence, when Talbi employs the term, umma, it is worth noting that he has consciously deconstructed the modern connotations of the word, divorcing it from the political meaning with which so many of his contemporaries have imbued it. In his view, a blurring of lines has occurred. Numerous terms are appropriate to describe membership within a secular group, so it is inherently interesting that writers have chosen to use the term umma for primarily political projects.

In exploration of this shift in meaning, Talbi discusses extensively the historical development, modern usage, and overlap with Western discourse of the term umma itself. In one of his earliest articles on the subject, written at a time when his thoughts on the implications of the shift in meaning were still taking form, he argues that each of us belongs to a multitude of communities at the same time, with varying degrees of size, openness, pluralism, and scope. ${ }^{16}$ Given the great number of terms the writer has at his disposal to describe affiliation, Talbi writes of the ramifications of each and the importance of the writer's choices. Part of the problem, he offers, is to be found in the Arabic language itself. Talbi notes that Western languages are rich with possibilities, as, "in both English and French, you find distinct words like nation, people, population and community." 17 These concepts have proven stable over time and leave little room for mutual encroachment. A Westerner who speaks of his nation is clear in his meaning and leaves little doubt that he might be speaking instead of his community. ${ }^{18}$

In Arabic, there is significant ambiguity in expressing the same concepts. Talbi suggests a number of words to signify nation, but ultimately rejects them all as unacceptable. As a result of this confusing gap in the Arabic language, many writers have attempted to use the word umma to mean nation in a Western sense. This usage has created its own "confusion in discourse, particularly political discourse."I9 As a result, when an Arab nationalist hears the word umma, he understands it in one way, and when an Islamist hears the same word, he understands it in another. ${ }^{20} \mathrm{~A}$

\footnotetext{
${ }^{15}$ M. Talbi, "La vie en communauté: Le point de vue d’un musulman,” Islamochristiana Io (I984), 85-90: 88.

${ }^{\text {I6 }}$ M. Talbi, "Une communauté de communautés: Le droit et la différence et les voies de l'harmonie," Islamochristiana 4 (I978), II-25.

${ }_{17}$ M. Talbi, Plaidoyer pour un Islam moderne, 34.

18 Ibid.

I9 Ibid.

20 Talbi goes on to note that the same process has occurred in a number of Western ideas adapted to the Arabic language, including liberty.
} 
secularist would understand the word in yet another way. This disparity has greater implications than the linguistic, Talbi writes; it has led to a dominant ambiguity throughout political discourse, to the detriment of constructive dialogue. In Talbi's words, "This is always to the detriment of precision of analysis and of an understanding of our situation." ${ }^{21}$ In brief, Talbi argues that there is a clear link between semantic confusion and confusion of thought. It is this unfortunate link that Talbi laments in his discussion of umma. In an attempt to clarify these ambiguities, Talbi presents his own analysis of umma, from its Qur'anic roots to its application in present reality.

Talbi argues that any discussion of umma must be rooted in the Qur'an. It is only from there that in his view we can trace deviation from the original meaning and projections that have arisen in subsequent literature. The primary verse that Talbi cites in this regard is found in Sürat al-Anbìyā', "Verily, this umma of yours is a single umma, and I am your Lord and Cherisher: therefore serve Me (and no other)." 22 Talbi argues that the two clauses of the verse are linked, so it can be inferred from the text that the umma is, "unique, indivisible and centred on the Greatness of God and service to Him." 23 As a single, undivided entity, the umma crosses racial, national, cultural, social, patriotic, political, and geographic boundaries, the fabric of which is formed of, "continuous prayer, in rows oriented around a unique centre, the sign of our spiritual unity, the Kaabah erected by Abraham." 24 The core of Talbi's argument is that all other definitions found in modern works represent a departure from this purely apolitical formulation.

Talbi goes on to discuss the verse, "Abraham was indeed an umma, devoutly obedient to Allah, (and) true in Faith, and he joined not gods with Allah" 25 a theme that is repeated in several places in the Bible. ${ }^{26}$ In this way, Talbi finds evidence of this assertion that the umma is to be defined as a community of monotheism, with the further specification that it arose with Abraham. Talbi writes that the meaning of the expression, "Abraham was an umma," was that, "Abraham was a community in himself, as he was the point of departure for a community of which the members are linked by monotheism." 27 The umma of Muslims, then, is an extension of the umma founded by Abraham. In this purely spiritual sense, Talbi argues, believers from China, Sweden, America, India, Tunisia, and Algeria are all members of the same community, in addition to their membership in other secular groupings.

\section{Is the umma political?}

Conflicting loyalties, including nation, race, ethnicity, gender, social groups, parties, and others are naturally quite real and serve to complicate our actions as humans. As a result, throughout history there have been attempts to reconcile the umma with the reality of diverse loyalties to form one single, neat political theory. Talbi notes, for example, that Abū al-Hasan

\footnotetext{
${ }^{21}$ M. Talbi, Plaidoyer pour un Islam moderne, 35.

${ }^{22}$ Qur'an 2I:92. Translation: Y. Ali, The Holy Qur'an (London: Wordsworth Editions Ltd., 2000).

23 M. Talbi, Plaidoyer pour un Islam moderne, 35.

24 Ibid.

25 Qur'an I6:I20. Translation: Y. Ali, The Holy Qur'an.

26 See, for instance, Genesis XII: I-2.

27 M. Talbi, Plaidoyer pour un Islam moderne, 36.
} 
'Alī al-Māwardī (972-IO58) attempted in his time to form a theory to reconcile the moral power of the Caliph and the actual power of the military. In doing so, however, Talbi argues that alMāwardī appealed to anachronism, attempting to justify his contemporary political surroundings with calls to early Islamic history. While al-Māwardī is a prominent example of the practice, he is hardly rare in the span of the history of Islamic literature. As Talbi sees it, "Such legal fictions emerged from the conditions of their era, the idea always being to reconcile a state of fact with the provisions of legal thought, with which they could not dispense." 28 In this manner, the fäqib seeks to back-project the political realities and values of his time to re-characterise the Qur'an and early Islamic history.

Talbi argues that a uniting reality, present since the death of the Prophet, is the lack of unity in a political sense within the umma. From the time immediately following the Prophet's death, Talbi notes, "If we were to place ourselves in that time, we would notice that members of the umma represent numerous peoples who could fight amongst each other and even kill amidst historical events." 29 This trend, Talbi contends, has continued to the present. When Muslims enter a mosque, "they form a community in the service of God"; 30 however, clashes of other loyalties and memberships are regular. In spite of their Islam, history and identity inspire myths which, in Talbi's words, "transform each man implicitly into an enemy of another human group."3I Contemporary history is filled with examples of this, including the Iran-Iraq War, where historical and religious symbols were employed by both nations to inspire hatred of the other.

The discussion of such identity projects in Arabic is in itself problematic. While governments and intellectuals freely use the term umma in a political sense, ${ }^{32}$ to comment on such usage in Arabic requires an explicit definition of terms. Talbi states that the responsible writer, when using umma outside of its Qur'anic context, should make note of the shift in meaning to remove ambiguity. In the very use of the term outside of its traditional contextual basis, however, one witnesses a concurrent discursive shift. Talbi presents the argument that this usage, even if it is a conscious choice on the part of the author, "continues ... to condition our minds." 33 The result is a word emptied of its spiritual meaning in the understanding of many readers. Such is the case when, for example, we speak of the United Nations - al-umam al-muttabida. Talbi contends that translations such as this, even when consciously employed, partially secularise the term.

Talbi asks rhetorically what the dangers are of a term such as umma that has been partially secularised in the minds of modern Muslims. He notes that we need only cast our attention to the manner in which terms such as jihäd and mujtabid have been manipulated in recent years to

\footnotetext{
${ }^{28}$ M. Talbi, Réflexion d'un musulman contemporain, 82.

29 M. Talbi, Plaidoyer pour un Islam moderne, 36.

30 Ibid.

3I Ibid, 53 .

32 Talbi excuses this widespread usage to some extent, explaining that there is no adequate translation of the word nation in Arabic. Some writers have attempted to use the term qawm, meaning a limited group, to fill the void, but Talbi dismisses this as inaccurate. In the minds of many writers, umma fills a void. A subtle redefinition of the term is required to employ it in a political or cultural sense, it is agreed, but it is the closest match possible among inexact candidates.
}

33 M. Talbi, Plaidoyer pour un Islam moderne, 36. 
understand the danger of such discursive shifts. Talbi strongly recommends that future generations of Arabic linguists occupy themselves with questions of original meaning and redefinition, as "Obscurity and ambiguity blind instruments of analysis, which were imprecise to begin with, to our reality." 34 Just as linguistic murkiness leads to intellectual ambiguity, Talbi argues, the minds of Arabic speakers cannot become clear until words are clarified.

The end result of the discursive shift that Talbi analyses is a shift in understanding, wherein large numbers of people in the Arab world have come to associate umma with the Western concept of nation. If the umma is to become a political entity, Talbi writes, the project of Islamists remains one of filling in the details of its practical operation ... and filling them in in such a way that it would seem they had always been there, in practice and in theory, from the time of the Prophet. Talbi, like many others in the modern age, is critical of such attempts. He cites the writing of ${ }^{\mathrm{C}} \mathrm{Ali}{ }^{\mathrm{c}} \mathrm{Abd}$ al-Rāziq (I888-I966) as an early rational voice against the Islamist project, in his effort to define din and dawla as independent. Talbi notes, however, that, "his attempt at secularisation failed, even if he did manage to leave disciples, and if his thoughts are implicitly practised in the Islamic world by necessity." 35 In spite of the position of the "ulamä' of al-Azhar, who widely held 'Abd al-Rāziq's work to be akin to bid'a (innovation), Talbi largely agrees with his thesis. The main shortcoming of 'Abd al-Rāziq's controversial argument, in his estimation, is the failure to acknowledge legal interpretation as conditioned by the context of the age, to let the practices of society as they exist in reality consciously drive the interpretation of the law. ${ }^{\mathrm{c}} \mathrm{Abd}$ al-Rāziq's work was received as revolutionary by his deterrents, while in reality it was simply a legal justification of a state of affairs that already existed throughout the Islamic world. Like Talbi's image of al-Māwardī, ' Abd al-Rāziq acted as a realist; his undertaking, like that of the great Shāfic $\overline{1}$ thinker, in Talbi's words, "can in any case be considered as the legitimisation after the fact of a state of fact, the fruit of evolution." ${ }^{36}$ In other words, like al-Māwardī, "Abd al-Rāziq engaged in what Talbi considers a quintessentially human behaviour, he sought to create religious legitimacy for a modern reality where none necessarily existed by virtue of sacred text alone.

Talbi refers to the pan-Islamism that was so central to the work of Jamāl al-Dīn al-Afghānī (I838-I897), including his treatment of umma, as "a mix of nostalgia and imagination." 37 The realist, in the modern sense of the word, like ${ }^{\mathrm{c}} \mathrm{Abd}$ al-Rāziq, would see the Islamic world as a forum for fights and division. Based on this, Talbi asks how current politics, from rifts between and internal to Muslim majority states, to the dissension within and subsequent paralysis of the Organisation of the Islamic Conference, ${ }^{38}$ can serve as a matrix for a political unity which has not been seen in over I,OOO years. ${ }^{39}$ Furthermore, he notes, a full 40 percent of members of the spiritual umma live in the diaspora, in countries where they constitute large and small minorities, like Russia, Albania, India, Great Britain, Germany, and the United States. ${ }^{40}$ The politicisation of ${ }^{40}$ M. Talbi, Réflexion d'un musulman contemporain, 85-6.

\footnotetext{
34 M. Talbi, Plaidoyer pour un Islam moderne, 37.

35 M. Talbi, Réflexion d'un musulman contemporain, 82.

36 Ibid.

37 Ibid, 85 .

${ }^{38}$ Now called the Organisation of Islamic Cooperation.

39 M. Talbi, Plaidoyer pour un Islam moderne, IO7-8.
} 
the umma would either leave this population behind, outside the fold, or would clash violently with the majority populations and secular traditions which characterise their homelands. In other countries, "in ever-increasing numbers, members of the umma share space with non-Muslims, as in Libya, Syria, Iraq, Egypt, and Sudan.”41

For that reason, Talbi refers to the political definition of the umma as a modern innovation, and one outside the scope of the universal ethical core that his project seeks to define. He maintains that Islam as both religion and state is not possible in the modern world. It clashes with the reality of the world in which Muslims live, and, thus, "all of the efforts undertaken to force the umma to enter the realm of the political, its organisation and assignment to the rungs of power in a uniquely 'Islamic' system, are absolutely unrealistic." ${ }^{2}$ For this reason, Talbi argues that political Islamists row countercurrent and often clash violently with those who acknowledge reality. The victories and defeats between the parties continue, but neither is able to claim success definitively. In Talbi's view, such debates form a vicious cycle, the only way out of which is to resume the 'reconstruction of Islamic thought,' a project advocated by Mohammed Iqbal (I877-I938) and the subject of Talbi's approval. ${ }^{43}$ The latter often makes reference to Iqbal, but regrettably does not define how his method would be incorporated into Talbi's own, a project that Talbi has stated he leaves to other scholars to pursue.

\section{Conclusion}

In the wake of the 20IO/II revolution in Tunisia, Talbi's ideas were revisited in the ongoing debate on the nature and place of Islamic politics and identity. In a period when the Arab media outside of Tunisia played an undeniable role in framing the dialogue on what it is to be Muslim and Tunisian, the question of umma - what it should mean for Muslims both within and beyond Tunisia -seemingly gained a new urgency. In this context, Talbi continued to contribute to the debate. His ideas on the discursive shift associated with the term umma remained constant, but he shifted in his approach to political Islam and the role of religion in government. While Talbi once argued that Islam should rightly inform the political at the level of abstract values, he revised his stance to something more akin to the French lä̈cité after 20 I I.

Talbi's late works and interviews on the subject - and the ideas that he promoted of a secularism rooted in the Qur'an and early Islamic history - attracted in the wake of the revolution and continue to attract a great deal of attention. In 20I5, he stated in an interview that,

Yes. Islam was born secular [laïque]. 'There is no compulsion in matters of religion.' The Quran is the only sacred book that contains this phrase, which is so clear, so secular. Everyone should practice the religion that he wants. The state may not interfere in religious affairs. It has one function: to create an atmosphere of peace for all. ${ }^{44}$

\footnotetext{
${ }^{4}$ I M. Talbi, Plaidoyer pour un Islam moderne, Io8.

42 Ibid.

43 See, for instance, M. Iqbal, The Reconstruction of Religious Thought in Islam (Madras: Kitab Bhavan, I930) wherein Iqbal argues that Muslims must move from a faith-based model of Islam to a model based upon discovery. His core idea is that modern Muslims must, using their own moral compass, experience the revelation of God's will much in the same way that the Prophet did.

44 F. Zouari, "Mohamed Talbi : 'L'islam est né laïc',' Jeune Afrique 9 January 2015.
} 
This was a significant departure from the positions of his early career, when Talbi criticised the methodology of political Islamists, but also argued that the universal ethical core that his method sought to derive could inform action, including political action. Addressing secularism, Talbi had once stated that it was fundamentally incompatible with Muslim societies. He had long argued against the broad application of secular ideas to Muslim states, contending that the problem with strict secularism is that, "the people in Muslim states are imbued with a diffuse but pervasive religiosity." 45 Otherwise stated, Talbi believed that there was a practical argument that strict secularism ignored the religious nature of Muslim societies and was naturally incompatible with the patterns of life within them.

Now, in contrast, his position was one of complete separation of faith and government. One senses that this recommendation found its roots in his disappointment with actual government behaviour, which always fell short of his ideals of religious dialogue, respect, and intellectual freedom. The Prophet, he contends, was "never seen running around the streets armed with a club, asking who is a Christian?' It is Arab conservatism that has triumphed in this area, and this drift has been attributed to Islam." 46 Thus, Talbi contends, Islamic states as they are found today exist and act in contradiction to the word and the spirit of the Qur'an. In his words at a 2015 conference, "what did the Islamic States do? They exercised religious restraint. The Quran [thus] says no to these Islamic states." 47 Talbi contrasts this with the true ethical core of Islam, which allows the believer to question, to debate, and to believe in an atmosphere of freedom. The state's most important obligation, then, is to protect that freedom to allow Muslims to exist in "modernity and rationality. The Qur'an is thus the call to reason, therefore to secularism." 48

Talbi's views brought a great deal of attention, both complementary and condemnatory, to his work and to his person. On one hand, by virtue of his fame as a writer in Tunisia and his many former students in key positions of the Tunisian government, universities and private institutions, his ideas have the power to drive both debate and action, even in the wake of his passing. On the other, his opposition to political Islam, his criticisms of modern Islamists and Islamic movements, and his frequent offhand statements such as "Aisha was a woman of few morals" have led numerous groups to accuse him of apostasy. He received multiple threats in the final years of his life, one in 2014 in graffiti on the wall of his Bardo home.

Still, Talbi continued pointedly to critique the association between Islam and politico-identity movements. In a 20I5 conference, Talbi took aim specifically at the legacy of Sayyid Quțb, when he said, "In separating faith and religious movement," Quṭb created a crisis of an intellectual nature, leading his adherents into transgression. He added that Quṭ, in his view, "had completely stripped Islam of its spiritual and social dimensions and turned it into a politico-religious instrument, detached from people's convictions and imposed on them," with the objective of laying the foundation of, in Talbi's words, "a religious state ... a state of darkness." 49 Such gov-

\footnotetext{
45 Interview with Mohamed Talbi, October 7, 2007, Tunis, Tunisia.

${ }^{46}$ F. Zouari, "Mohamed Talbi : 'L'islam est né laïc',' Jeune Afrique 9 January 2015.

47 Reported in: F. Zouari, "Mohamed Talbi : 'L'islam est né laïc',' Jeune Afrique 9 January 2015.

$4^{8}$ F. Zouari, "Mohamed Talbi : 'L'islam est né laïc',' Jeune Afrique 9 January 2015.

49 Conference quotation found in: "Tunisian Islamic scholar Mohamed Talbi, a fierce opponent of fundamentalism," The Arab Weekly IO5 (20I7), 23.
} 
ernance in Talbi's view brings with it the risk of an environment where Islam is reduced to mere ritual and institutions without belief, where identity trumps faith. Talbi was adamant that he found this to be a most dangerous state of affairs, divorcing Muslims from the light of God's true ethical message and relegating Muslim societies to a state of backwardness.

Still, up to the very end of his life, Talbi remained hopeful about the future of Muslim societies. In spite of his grave warnings, he wrote, "If I were not confident in the future of Islam, would I have taken the pen to write? We do not write when we are pessimistic. I maintain that Islam is destined to return to its original purity." 50 This optimism is perhaps why Talbi's writing continues to resonate, informing debate in the wake of the Tunisian revolution and continuing to drive discussions on the nature of religion, society, and government in Tunisia. Less than a year after his death, a conference and a seminar on Islamic thought and the future of Islamic modernism were planned in his honour. Islamism and secularism continue to co-exist uneasily in the Tunisian public space, and thus, an internally cohesive methodology that allows for the reconciliation of Islamic sacred text and secular governance remains attractive to some and extremely controversial for others. That this debate should be taken up by a younger generation, inspired by his own work or not, was always Talbi's hope. Commenting on the future after his passing, Talbi stated two years before his death, "I console myself by comparing myself to a salad shop. I plant my vegetables. I put them on the market. I do not impose them on anyone. If someone comes to buy them, it's his business. He bears the responsibility, not me." ${ }^{\mathrm{I}} \mathrm{I}$ In the coming years, this author will continue to watch Talbi's salad shop with interest to see in the ever-changing landscape of Tunisian political and religious thought what kind of vegetables it bears.

\footnotetext{
${ }^{50}$ F. Zouari , “Mohamed Talbi : 'L'islam est né laïc',' Jeune Afrique 9 January 2015.

5I Ibid.
} 